\title{
A PERIPATUS FROM BARBADOS
}

\author{
By ClaAdio G. FROEHLICH
}

No species of Peripatus was known from Barbados, British West Indies. As a matter of fact, onychophores were supposed to be absent from this island on account of its greater isolation from the other Lesser Antilles, and the nature of its fauna (Clark, 1915; cf. also Cuénot, 1949, p. 34) . Recently, however, the Rev. E. J. Pearce succeeded in discovering some examples of Peripatus in Barbados, one of which he sent to Prof. Dr. Ernst Marcus, head of our Department, and two others he deposited in the Science Museum of the Jamaica Institute. Prof. Marcus handed over his specimen to me for determination, and the two specimens of the Jamaica Institute were also kindly forwarded to me. The specimens proved to be a form closely related to Peripatus dominicae Pollard, 1894, of which I consider it to be a new subspecies.

\section{PERIPATUS (s. str.) DOMINICAE BARBADENSIS, n. subsp.}

All three specimens are females with 31 pairs of legs. Their sizes are $32 \mathrm{~mm}$. long by $4.5 \mathrm{~mm}$. broad, $25 \mathrm{~mm}$. by $4 \mathrm{~mm}$., and $17 \mathrm{~mm}$. by $2 \mathrm{~mm}$., resp. The latter is very young. The body is broader than high, the dorsal side is convex, the ventral flat to slightly concave. In the middle-sized specimen, which appears to be somewhat shrunken, the dorsal surface is depressed along a line on each side, resulting in a three-lobed appearance. The colour of the preserved specimens is a uniform reddish-brown above, due in a large measure to the colour of the subepidermal muscles. The middle-sized specimen is much the darker one. The scales of the papillae are brown, the rest of the scales are lighter in colour (fig. 1). The middorsal light line is more distinct on alternate plicae. On a narrow band on each side of the light line the skin scales are all dark and, as a rule, no principal papillae occur (figs. 1-5). The light organs (hyaline organs, "organes 
claires") are hardly visible. As usual, the ventral side is lighter than the dorsal.

There are 12 plicae per segment on the back, but at the level of each pair of legs two of them are incomplete, ending about halfway to the margins (figs. 3-5). Seven of the plicae generally pass to the ventral side, where they are continuous. Between these, irregular plicae occur. The ventral organs are distinct, the preventral ones also frequently so.

The youngest specimen has large principal papillae separated by one to six or occasionally even more accessory papillae; the most common number is three, of which the middle one is larger. All papillae are on the crest of the plicae and the principal ones are manifestly prominent (fig. 5). The middle-sized specimen presents small to mecium-sized accessory papillae on the slopes of the plicae, besides those on the crest (fig. 4). In the largest specimen the distribution of the papillae is similar, but the plicae are broader and the furrows less deep (fig. 3 ). The basal diameter of the larger accessory papillae is about the same as that of the smaller principal ones, but on the whole the principal papillae appear clearly dominant. The principal papillae have a conical base and an upper part which is rather short and conical in the mesial papillae (fig. 6) but gets longer and cylindrical toward the margins (figs. 7-9). The terminal spine is commonly almost as long as the upper cylinder. The principal papillae of contiguous or of alternate plicae may be disposed in short longitudinal rows.

The antennae, which are about as dark as the dorsal side, have ca. 42 large rings. The eyes are small, measuring $130 \times 90 \mu$ in the largest specimen. The frontal organs are present, their length corresponding to three or four principal papillae of the ocular ring.

Both blades of the jaw (fig. 10) have but one accessory tooth. The saw of the inner blade has 9 denticles in the largest specimen, 8 in the smallest. The denticles diminish slightly in size backwards. The buccal crest ("tongue") has 9 denticles and, at its posterior end, 3 or 4 minute lateral spines.

The creeping pad of the feet comprises four arcs. The papillae of the row next to the fourth arc are mostly spiny as the pad, and some 
occasionally coalesce, forming rudiments of a fifth arc. The nephridial tubercle of the fourth and fifth pairs of legs is independent of the third arc in all specimens. The third arc is a little emarginate and the fourth pushed aside by the tubercle.

The largest specimen has been dissected. The salivary glands extend to the fourth preanal legs, its reservoir to the second leg-bearing segment. The funicle of the ovaries is long and simple. The ovaries are short and are located at the level of the twelfth preanal legs. The ovoid seminal receptacles are $250 \times 300 \mu$. Two advanced embryos, one in the terminal part of each uterus, are close to $20 \mathrm{~mm}$. long by $1.5 \mathrm{~mm}$. broad. Both have 31 pairs of legs and seem to be females.

Collection Data. St. John, Barbados, B. W. I., The Rev. E. J. Pearce coll.: Holotype,$+ 32 \mathrm{~mm}$. long, on leaf mould, Codrington College, 5. viii. 1960 (Dept. of Zoology, Fac. of Philosophy, Univ. of São Paulo). Paratype $q$ ㅇ, $25 \mathrm{~mm}$. and $17 \mathrm{~mm}$. long resp., Codrington College Grounds, Sept. 1960 (Science Mus., Jamaica Inst.) . According to the collector (letter of Nov. 9th, 1960): "I was surprised to find Peripatus here, as I would have thought that our frequent very dry periods would not provide sufficiently humid conditions for its survival here. I have so far found it in two different localities on Barbados, some miles apart. It seems to be decidedly rare here."

\section{DISCUSSION}

Peripatus dominicae barbadensis is closely related to the type subspecies and to $P$. $d$. antiguensis Bouv. The distribution of the skin papillae is much the same as in dominicae s. str., our largest specimen being in this respect very similar to the one picture by Bouvier, 1905, pl. VII, fig. 59. As regards the smallest specimen, the scarcity or absence of accessory papillae on the slopes of the ridges is usual in young specimens of Peripatus s. lato. The number of pairs of legs in five females (two of them advanced embryos) is 31 , indicating a slightly higher average than in dominicae s. str., which has 29 or 30 pairs as the most common numbers. Females of antiguensis have from 29 to 31 pairs. The nephridial tubercle of the fourth and fifth legs is independent of the third arc as in antiguensis. In dominicae s. str. it is connected to the third arc by a narrow bridge. 
As regards the internal anatomy, the salivary glands, of three forms under discussion are similar. The ovaries and seminal receptacles of barbadensis, being about the level of the 12th and 13th preanal legs, are much in advance than in either dominicae s. str. or antiguensis and resemble those of one female of $P$. $d$. juanensis Bouv., in which the ovaries were at the level of the 14th preanal legs. In the other female of the same form examined by Bouvier, however, the cvaries were at the level of the 7th preanal legs (Bouvier, 1. c., p. 268). If Bouvier had really homogenous material, then this character cannot be much reliable for taxonomic purposes.

Some forms from Haiti described by Brues, 1935, as varieties of dominicae, viz. basilensis, darlingtoni and lachauxensis, differ rather widely from dominicae s. str. and its closer "varieties" in the distribution of skin papillae, number of legs, or number of denticles of the saw of the inner jaw blades. Their taxonomic position merits a revision, which at the moment I am unable to carry on.

\section{FURTHER REMARKS}

The occurrence of Peripatus in Barbados raises some zoogeographic and other problems. Barbados is a very young island, its last emergence dating from late Pleistocene to Recent (see Schuchert, 1935; Beard, 1949; Woodring, 1954). Both its terrestrial fauna and. flora have the character of accidental arrivals. Any land connection with neighbouring islands is out of question, so the Peripatus of Barbados could only have arrived as waifs or through human agency. Waif transport has been considered absolutely impossible for onychophores but, as has happened in some other cases of animal dispersion, that notion may prove to be wrong (see Darlington, 1938). In either case, the establishment of Peripatus in Barbados must be a relatively recent event. One may ask if their isolation has been sufficiently long to allow a significant degree of variation from the parent stock, so as to deserve a special name. As, however, of all known forms none fits entirely, the most similar being discussed above, I thought it more prudent to distinguish it from its near relatives. As a matter of fact, the onychophore fauna of the West Indies (and, for that matter, that of Latin America generally) is only partly 
known. Some forms, like $P$. danicus Bouv. from St. Thomas, $P$. bavayi Bouv. from Guadeloupe, and the form from Carriacou (Brues, 1914), are insufficiently known; others probably have not yet been found. No species of Peripatus is known, for example, from St. Lucia or Martinique, there being no apparent reason for their absence in these islands.

From the Science Museum of the Jamaica Institute I received also a specimen collected in British Guiana by the Rev. Pearce. The specimien is a female, ca. $38 \mathrm{~mm}$. long, with 30 pairs of legs, dark purplish-brown on the back, lighter below. Although badly macerated, it can be identified with Peripatus (Epiperipatus) imthurmi Sclater. Collection data: Wakapor, Pomeroon, British Guiana, 8. viii. 1959. The Rev. E. J. Pearce coll.

\section{RESUMO}

Peripatus (s. str.) dominicae barbadensis, n. subsp., proveniente dá ilha de Barbados nas Pequenas Antilhas, é descrito. A nova subespécie assemelha-se a $P . d$. dominicae e a $P . d$. antiguensis. Aproxima-se da primeira pela distribuição das papilas da pele, da segunda pela disposição do tubérculo excretor do $4 .^{\circ}$ e $5 .^{\circ}$ pares de patas, que é independente do $3 .^{\circ}$ arco do pé. Todos exemplares da nova subespécie têm 31 pares de patas, o que indicaria ter em média um a dois pares a mais que as duas outras subespécies.

A ocorrência de Peripatus em Barbados é de interêsse zoogeogcáfico. Barbados emergiu muito recentemente e até seu ponto culminante, $330 \mathrm{~m}$ acima do nível do mar, é recoberto por corais do Pleistoceno. Desde sua emergência está seguramente isolada. Por outro lado, os onicóforos são animais muito sensíveis a condições adversaıs, o que levou vários autores a considerar impossível para êsses anirnais dispersão acidental que implicasse travessia de mar. Darlington, 1938, contudo, acredita que as Antilhds, exceto Trinidad, foram colonizadas inteiramente por sêres que, de qualquer forma, atravessaram o mar. A ocorrência de Peripatus em Barbados, se não se deve à interferência humana, só pode ser explicada por travessia acidental do mar. A pátria de origem de $P$. $d$. barbadensis ainda não pode ser determinada. 
Um exemplar proveniente da Guiana Britânica, apesar de mal conservado, pode ser classificado como Peripatus (Epiperipatus) imthurmi Sclater. Tanto os exemplares de Barbados, como o último, foram colecionados pelo Rev. E. J. Pearce.

\section{REFERENCES}

BFARD, J. S., 1949 - The Natural Vegetation of the Windward and Leeward Islands. Oxford Forestry Mem. No. 21, 192 pp., 52 tigs.

BOUVIER, E.-L., 1905 -- Monographie des Onychophores. Part I. Ann. Sci. Nat., ser. 9, vol. 2, nos. 1-3, pp. 1-383, 140 text-figs., 13 pls.

RRUES, C. T., 1914 - A new Peripatus from Colombia. Bull. Mus. Comp. Zool., vol. 58, pp. 375-382, 2 pls.

— 1935 - Varietal forms of Peripatus from Haiti. Psyche, vol. 42, pp. 58-62.

CLARK, A. H., 1915 - The present distribution of the Onychophora, a group of terrestrial invertebrates. Smithsonian Misc. Coll., vol. 65, n. ${ }^{0} 1$, pp. 1-25.

ClínOT, L., 1949 - Les Onychophores. Traité de Zoologie, ed. by Pierre-P. Grassé, vol. VI, pp. 3-37, 37 textfigs.

DARLINGTON, P. J., Jr., 1938 - The origin of the fauna of the Greater Antilles, with discussion of dispersal of animals over water and through the air. Quart. Rev. Biol., vol. 13, n. ${ }^{\circ}$ 3, pp. 274-300, 5 figs.

PGLLARD, E. C., 1894 - Notes on the Peripatus of Dominica. Quart. J. Micr. Sci., vol. 35, n. ${ }^{\circ} 138$, pp. 285-293, pl. 17.

SCHUCHERT, C., 1935 - Historical Geology of the Antillean-Caribbean Region, 811 pp., illustr. John Wiley and Sons, New York.

WOODRING, W. P., 1954 - Caribbean Land and Sea through the Ages. Bull. Geol. Soc. Amer., vol. 65, no. 8, pp. 719-732, 3 text-figs., 1 pl. 
C. G. FROEHLICH - PERIPATUS FROM BARBADOS - PLATE 1
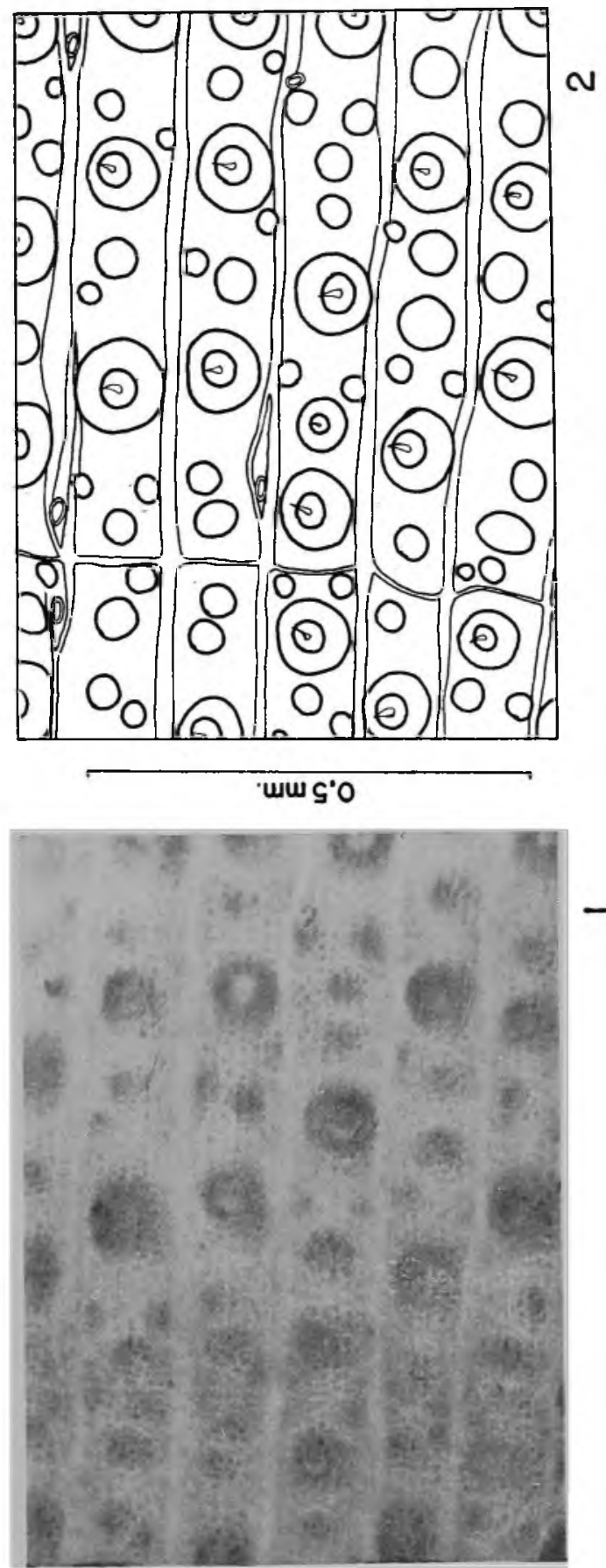


\section{EXPLANATION OF THE FIGURES}

Fig. 1 - Holotype. Photograph of skin at the level of the 16th pair of legs: skin scales, papillae, median light line, and some spiracles.

Fig. 2 - Ink outline of the same. The spiracles are drawn with double thin lines.

Fig. 3 - Holotype. Skin of the same region as above: distribution of principal and accessory papillae, two incomplete plicae, and median light line.

Fig. 4 - Larger Paratype. Skin at the level of the 15 th pair of legs: same structures as in fig. 3 .

Fig. 5 - Smaller Paratype. Skin at the level of the 14th pair of legs: same structures as in fig. 3 .

Fig. 6 - Larger Paratype. A principal and an accessory papilla close to the median line.

Fig. 7 - Ibid. A principal papilla of the lateral portions of the body .

Fig. 8 - Holotype. Outline of a principal papilla close to the legs.

Fig. 9 - Ibid. Upper cylinder of another principal papilla of the same area.

Fig. 10 - Outer and inner blades of the jaw.

Figs. 3-10 are camera lucida drawings. Figs. 3-5 drawn to scale above fig. 5; figs. 6-9 to scale above fig. 6 . The skins and papillae figured are all from the dorsal surface. 
C. G. FROEHLICH - PERIPATUS FROM BARBADOS - PlATE 2

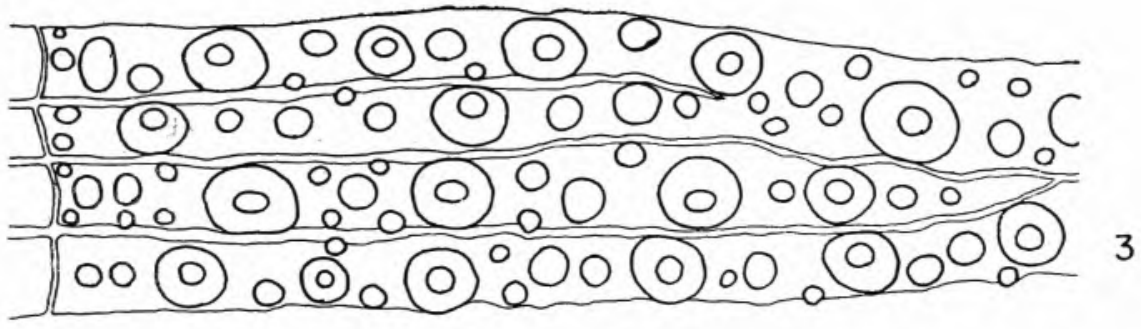

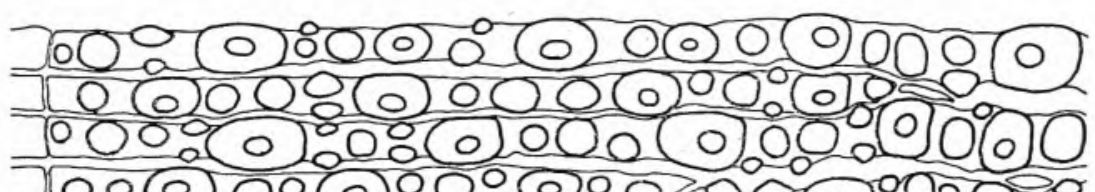

J000)00(000000000000000 4

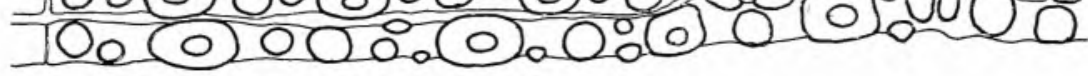

$0.5 \mathrm{~mm}$.

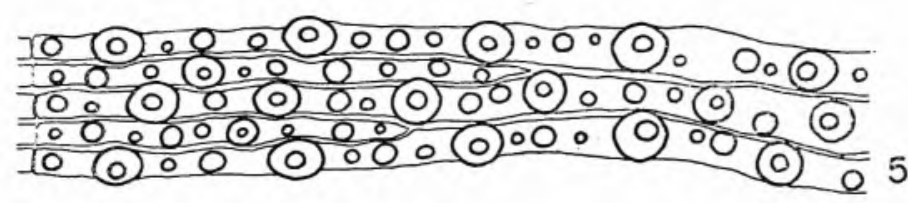
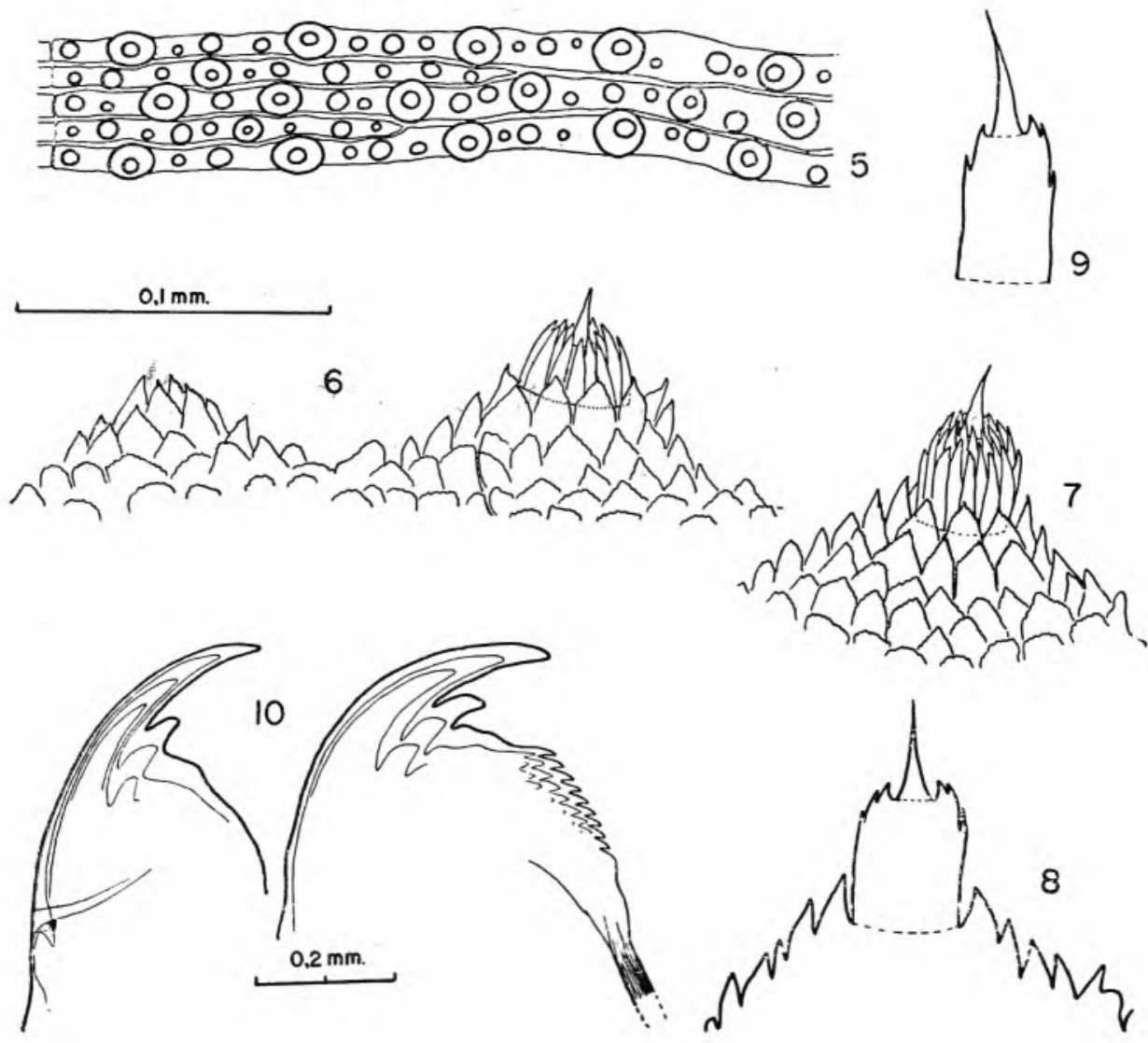
